\title{
Investigating Strategies and Problems on E-Learning Application in Madrasah to Develop Students' Literacy
}

\author{
Abdul Munif ${ }^{1, *}$ \\ ${ }^{1}$ Madrasah Ibtidaiyah Negeri 1 Gresik, Gresik, Indonesia \\ "Corresponding author.Email: abdulmunif819@gmail.com
}

\begin{abstract}
The objective of this research was observe the applied strategies and the problems faced by teachers in conducting elearning as distance learning during this COVID-19 outbreak to develop student's literacy. This research used descriptive qualitative method by analyzing documentary study on e-learning madrasah to what extent the participation level of the students and teachers used and joined in it and field study related to available server.The findings showed that there were three teaching strategies applied by the teachers. They applied only online, using video conference, and combining both of them in online teaching and learning process through WhatsApp. Research data sources were collected through participation of the students and teachers in online form of e-learning madrasah, students' tasks, articles from periodical journal websites, and other sources which were relevant to the research problem. Some problems arose during distance learning using platform e-learning madrasah were teachers' disability in accessing technology, school facilities in supporting e-learning, the difficulties in explaining the material, students' limitation in accessing the internet, students' economically disadvantaged family background, parents' support system, and lack of socialization of the use of e-learning for madrasah students, teachers, and parent. Based on the seven above findings, it was concluded that most of the students and teachers did not use madrasah e-learning because they prefer studying by using WhatsApp to e-learning madrasah to develop literacy.
\end{abstract}

Keywords: E-Learning Madrasah, Distance learning, Digital era, Literacy.

\section{INTRODUCTION}

The transformation of the digital era is emerging and cannot be avoided in the era of the industrial revolution 4.0. In the midst of uncertain and complex of the changing world, it is necessary to provide the information services that can be accessed without limits. Globalization means worldwide which no longer recognizes distance, space, and time. The industrial revolution 4.0 is the answer to bring solutions the changes in the information of technology era. WhatsApp is one of the tools to increase the instant communication for being made an online book that creates friendly atmosphere and develop student's literacy [1]. The changes of the digital era have a significant impact on the way of the human work, from traditional services to digital-based services and data sources, especially during the COVID-19 pandemic [2].

Education is the right way to change individual mindsets for the better in transforming values, culture, and technology. Education is as the front line in building superior and competitive human resources. Education should not stop in any situation, despite the current global pandemic outbreak, including in Indonesia. During the global pandemic of covid-19, learning activities have to continue and seek for alternative solutions, one of which is through online learning as the substitute for face-toface learning to curb the spread of the virus. Online learning becomes more and more prominent during the pandemic by utilizing of the learning management system (LMS) [3].

During the covid-19 pandemic, the learning methods experienced learning shifts, one of which is the shift into the use of distance learning. This condition certainly brings consequences for teachers to adapt in mastering and using technology through online learning which is an important part during periods of isolation and social distancing[4]. The teachers expected to adapt professionally amidst the changing behaviors [5]. It is undeniable that during this pandemic, some teachers also experienced some problems in delivering material through online learning due to a lack of mastery of 
technology. It is expected that the teachers are able and ready to face various changes in the global era so that they are not technology alienated. The scope of problems on this research is the use of e-learning designed for madrasah to accommodate distance learning and also issues on the application of the e-learning. Previous study by Lestiyanawati [6] suggested at least six problems for teachers in conducting e-learning system during the pandemic, namely teachers' disability to apply and access technology, students' supporting tool (Smartphone) as media to access for learning, the students from economically-disadvantaged family, students' networking area, the difficulty of teachers how to explain the material to students, and parents' support to their children to stay joining in learning process through e-learning. Based on the research, students and teachers were interviewed, and more than half of them $(58,9 \%)$ agreed with the use of WhatsApp as e-learning process. The results of the research have similar issues on applying the e-learning madrasah during the distance learning. Students, teachers, and parents seem familiar to use WhatsApp than e-learning madrasah. Despite the fact that some features of e-learning madrasah are more sophisticated than WhatsApp like their ability to record all documents of learning, however, they prefer WhatsApp to e-learning madrasah. Relevant with the use of e-learning, a review study by Coman [7] asserts that the students experienced challenges in processing information through e-learning; $41,3 \%$ of the students would prefer the teaching and learning in combination between online and offline (in-person) learning.

The current global era requires the role of teachers to master technology as part of managing the learning system. Using various media is to support effective learning. Students and teachers utilize media from various sources such as the Internet to encourage creative and innovative learning. It is believed that online learning affects the achievement and mastery and student's learning outcomes [2]. Parents and teachers have to collaborate and communicate to supervise their children during distance learning in order to realize independent learning. Parents often feel sorry for their children in solving every problem of learning difficulty. Parents always provide assistance to solve problems experienced by the children. The way the parents give assistance to their children affects to children's independence.

In the situation of COVID-19 pandemic which requires everybody works from home, teacher's competence has indirectly increased. This improvement of this competency is based on rapid and sporadic migration and adaptation when online learning has been implemented. Online learning requires teachers' skills to master the technology. Teachers must be able to migrate from traditional to online learning[8], [9]. The change always brings impact that each teacher has to be able to adapt in the change of new situation. The change always brings implications that are sometimes uncomfortable.
The discomfort is due to being in the comfort zone. Someone who makes the changes is a someone who wants to develop his ability to constantly adapt to the situation. Adaptability urges someone to create innovation. Teachers who always innovate indicates that they always want to change according to the conditions they face; the willingness to innovate is in line with increasing teacher's professionalism.

In disruptive era, it becomes a valuable moment for teachers to be able to innovate in utilizing various media to support learning. The available media may be obtained and accessed easily and freely through the Internet. Teachers may synergize and collaborate with colleagues to develop and use learning media during the pandemic and even post-pandemic. Teachers' ability to develop and use media is basically part of the teacher's efforts to develop self-competence.

During distance learning, the learning activities are carried out by the teacher are very diverse. Many choices of media are used to facilitate students' learning activities during distance learning. The media are used by the teachers from simpler to more complex such as learning management system (LMS). The choice of using media is adjusted to the readiness of the institution, students, parents, and teachers as users. Several choices of media that can be used during distance learning included WhatsApp, Google Classroom, Microsoft 365, Zenius, Quipper, and other applications prepared by each institution to develop student's literacy [10], [11].

Educational institutions play a very important role in providing facilities to support distance learning. This infrastructure support can be in the form of an internet network with adequate servers. Further support is in the form of learning resources that can be used by teachers and students who have limited supporting learning tools. These learning resources are used as digital learning tools appropriately to support and improve academic quality as a process of feedback and student responses with teachers or even parents [12]. One of the learning resource platforms that can be used in distance learning can be Google Classroom, which is quite complete and easy to operate and help students to organize self-regulated learning activities. Self-regulated learning may guide and control students effectively and efficiently as a form of responsibility to learn independently [13]. Google Classroom is as one of the platforms which is used for distance learning activities because it provides various integrated system. The integration system can be managed through the content menu, interaction, assessment, and task collection processes [4]. In addition, it can be modified by means of collaborative learning that is designed synchronously and asynchronously with the aim of facilitating learning interactions.

The $21^{\text {st }}$ century learning is not only personal skills but collaboration skills that may combine various elements into a source of strength. Working 
independently is not be optimal, while on the contrary working together and collaborating is more effective and efficient to speed up and facilitate the completion of work. The effectiveness of distance learning is influenced by the readiness of the e-learning infrastructure itself and the understanding of knowledge which is possessed by both teachers and students [14], [15].

To fulfill of supporting facilities for the $21^{\text {st }}$ century learning has to be a priority program for educational institutions supported by the government and the community. The Ministry of Religious affairs looks for the innovation to improve the quality of education in madrasah and Islamic universities through various improvement efforts such as infrastructure, institutional arrangement, and human resource training. One of the infrastructure developments made by the Ministry of Religious affairs to build a digital madrasah program to provide the madrasah students to be able to compete globally in the era of the industrial revolution 4.0. Elearning madrasah is one of the digital learning system management platforms provided by the government.

Based on the above cases, this research intends to observe the impact of using e-learning madrasah and the appropriate strategies to accommodate the impact of using e-learning madrasah during covid-19 pandemic to develop students' literacy.

\section{METHODS}

Before the pandemic, the use of e-learning madrasah was limited until the covid-19 pandemic. Few teachers used the e-learning madrasah platform as teaching learning tool, and the pandemic has forced most of the teachers and also students to move, in a very short time, from traditional learning to exclusively online learning.

This is a descriptive qualitative study with a case study approach. Data were collected from e-learning madrasah platform and analyzed. The participants were students and teachers of Public Madrasah Ibtidaiyah (MIN) 1 Gresik as participants. The population of this study consisted of teachers and students who were chosen randomly. The data were collected through interview and recorded from students and teachers' activities who used of e-learning madrasah, including reports on meetings between headmaster and teachers regarding the progress of the development of using e-learning madrasah platform during the covid-19 pandemic. The method was used based on various information from scientific articles from various national and international journals.

\section{RESULTS AND DISCUSSION}

The use of e-learning madrasah was very helpful for teachers, students, headmaster, and supervisors for learning activities during the pandemic. E-learning madrasah has complete features in managing and presenting learning materials. The platform is the ministerial program to develop an integrate learning administration system for Islamic education. For teachers, e-learning madrasah is an application innovation that strongly supports teacher's activities in designing, presenting, and assessing learning activities to students. For planning a lesson, teachers may create a lesson plan in the Lesson Planning menu by selecting the time settings, themes, and competencies achieved in the pre-set learning. Students could use the e-learning madrasah application by joining via the link shared by the teacher or the teacher directly added student data to the e- learning madrasah application.

When student's data were recorded on the application of e-learning madrasah, students could use it. Students could sign in and operate the activities independently using their own usernames and passwords. Students could see, use, and monitor the learning activities given by the teacher. Students could see the plans made by the teacher, including learning materials, learning resources, learning media, and learning assessments that were prepared by the teacher for each learning activity. Students could see various forms of learning media prepared by the teacher in the form of word, PDF, video, or external links. The menus were expected to motivate students to learn better, so they were accustomed to facing the activities of digital era. The activities of student learning could be monitored by the teacher through track data record when logged in. In addition, students could also communicate both in writing through comment spaces of e-learning or verbally during an integrated face-to-face session.

The integration of the facilities in the e-learning madrasah can be used by the headmaster and supervisor to monitor and evaluate activities. The headmaster and supervisor could observe the activities of the teacher who used the application for learning activities. This integrated monitoring system made easier for the headmaster and supervisors to check anytime and anywhere. Students, teachers, headmaster, and supervisor experience the advantages from the application of e-learning madrasah. Teachers could apply offline and online (blended learning models) as an evolution of the distance education system even though the situation would be normal without the COVID-19 pandemic later [16]. Furthermore, teachers were also easier to manage learning administration data because it was recorded by the system. This administrative management system was very good because it no longer uses paper, thus reducing the use of paper. Likewise, every student's work and submission of assignments could be in the form of document, PDF, photos, or links. The result of this research showed as in the diagram. 


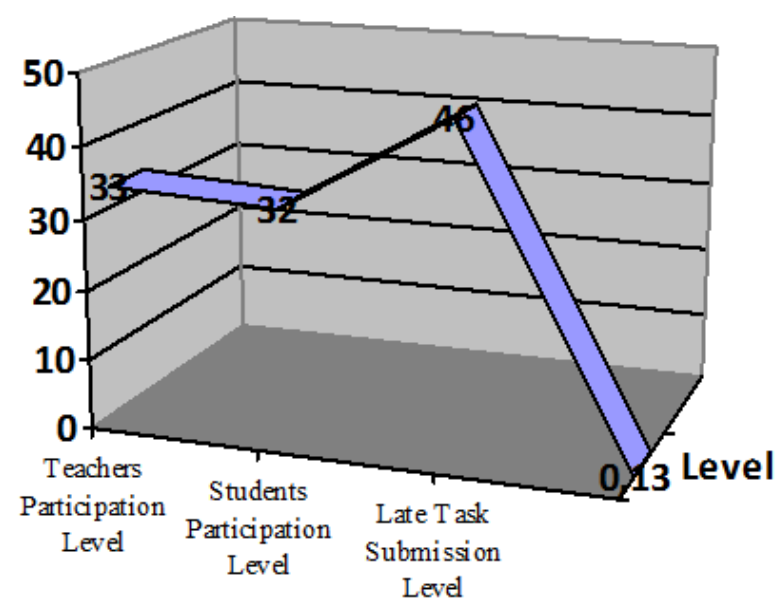

Figure 1 Diagram of participation levels

In order to implement the e-learning madrasah optimally, it was necessary to socialize and introduce elearning madrasah to teachers, parents, students, and stakeholders as it was needed to give understanding to the madrasah community. Since the implementation of studying from home, various models of learning tools had been applied by teachers, even though in fact the elearning madrasah became the main application.

There were some issues the teacher did not utilize the e-learning madrasah in learning activities. Firstly, low grade students found it difficult to recognize various features that exist in e-learning. Second, teachers felt unfamiliar with the e-learning applications, so they experienced difficulties to utilize in the classroom. Third, teachers who taught in high grades did not entirely use elearning for various reasons. Both teachers who taught in low and high grades prefer other applications in the form of WhatsApp as the learning support application. WhatsApp application was considered quite practical because it was better known and easy to use, including by the students. However, the appearance and other features that support learning activities were still not comparable to those provided in e-learning madrasah. In this case, technology and communication may cause processing of changing in learning[17].

Actually, the introduction of e-learning was conducted to the teachers at the beginning of the pandemic. The goal was that e-learning madrasah became the alternative virtual classroom used by the teachers during distance learning. Due to the low commitment on the use of e-learning madrasah to the teachers, e-learning was not utilized by all teachers in learning. Evaluation and supervision to the use of elearning madrasah carried out by the headmaster and supervisor had also not been able to maximize teachers' utilization of the application.

There were some factors that became challenges why the application of e-learning madrasah had not been used optimally by the teachers, namely the teachers were not been emphasized on using e-learning madrasah that it could be seen when some teachers who used e-learning madrasah did not receive a positive response; it was not uncommon to weaken other teachers, thus they were not using e-learning madrasah. In addition, the complaints from the students' parents who could not facilitate their children' need through the Smartphone.

Supporting device is expected to create the sustainability of learning to increase the students' ability to use available technology and infrastructure [18]. Some students may face different problems, some of which is that the students or family may have only one Smartphone - belongs to the parents and used for work. The cost of internet data packages increases which caused extra budget. Another challenge is the server access often got in problems. It made in difficult for teachers and students to log in to e-learning applications. The parents assumed that e-learning madrasah made students faced in difficulty for learning because they were considered unable to operate it. Some issues have been anticipated and accommodated by the school such as providing several computer units at madrasah to support facilities that could be utilized by students who had limited devices.

The supporting facilities in the form of computers provided by madrasah had not been used optimally by the students and parents for various reasons including the distance from home to school was too far - the parents did not have time to take their children. There were actually not many cases faced by students who did not have supporting devices. The issues as described above could not be avoided as the part of the impact of learning in the digital era, not only experienced in Indonesia but also in the whole world who experienced similar problems. Distance learning through learning system management (LMS) was the way to be followed because there was a systematic organization of material in it. It was a necessity that the implementation of a system would have an impact on the way things of work, but working without a system resulted in non-optimal work services.

There were some problems influenced during covid19 pandemic using e learning [19], namely the supporting infrastructure for online learning had not fully reached the area where students lived, the dominant use of the internet among students allowed to health problems, the ability of the parents to fulfill the supporting facilities for their children due to limited funds, the internet speed and availability of supporting infrastructure, and students' 
cognitive competencies that affect the success of distance learning [19] [20].

The impact of the ineffective use of e-learning was students may experience learning loss. To solve the problems was to socialize to the students and teachers about using e-learning madrasah and increase students and teachers' technical skill how to integrate e-learning madrasah in learning process. Technical issues were the most important such as teachers' lack of technical skills and their teaching style adapted to the online

Table 1. Teachers and staff

\begin{tabular}{|c|l|l|l|}
\hline \multirow{2}{*}{ No } & \multicolumn{3}{|c|}{ Teachers And Staff } \\
\cline { 2 - 4 } & Position & $\begin{array}{c}\text { Government } \\
\text { officials }\end{array}$ & $\begin{array}{c}\text { Non- } \\
\text { government } \\
\text { officials }\end{array}$ \\
\hline 1 & Teachers & 25 & 6 \\
\hline 2 & Staff & - & 4 \\
\hline 3 & $\begin{array}{l}\text { Security and } \\
\text { CS }\end{array}$ & - & 4 \\
\hline
\end{tabular}

environment. Through its complex characteristics and diverse features, e-learning madrasah could enhance the educational process. However, it influenced collaboration and performance of the teachers and students positively. They had to know how to integrate it effectively into the teaching and learning process. The following are the data of teachers and academic staff.

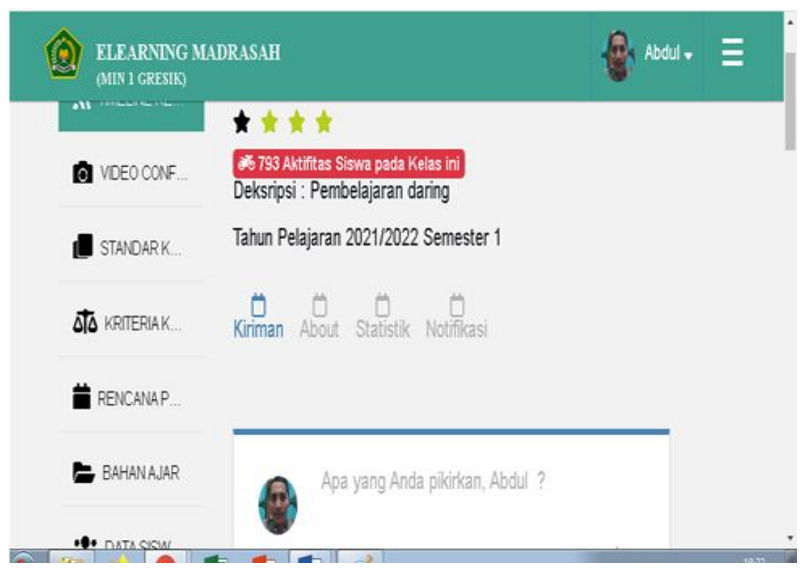

Figure 2 e- learning madrasah

\section{CONCLUSION}

The use of e-learning madrasah to develop student's literacy is very helpful for distance learning if it was implemented and managed with the availability of supporting devices. Supporting devices that have been owned by the students were in the form of Smartphones compatible with the requirement to access the applications of e-learning madrasah. Another factor that affects the implementation of the e-learning is the stable server and internet network.

\section{AUTHOR CONTRIBUTIONS}

The author conceived and designed this study and contributed to the process of revising the manuscript, and at the end, the author has approved the final version of this manuscript.

\section{ACKNOWLEDGMENTS}

I am enormously grateful to the headmaster of MIN 1 Gresik who gave support, including the teachers and academic staff of the school. I am especially grateful to the committee of ICMR for your encouragement, kind advise, and assistance throughout my research.

\section{REFERENCES}

[1] K. Jailobaev, M. Baialieva, G. Baialieva, G. Asilbekova, WhatsApp Groups in Social Research: New Opportunities for Fieldwork Communication and Management, Bulletin of Sociological Methodology/Bulletin de Méthodologie Sociologique, 149(1) (2021) 60-82. DOI: $10.1177 / 0759106320978337$.

[2] W.A.F. Dewi, Dampak COVID-19 terhadap Implementasi Pembelajaran Daring di Sekolah Dasar, Jurnal Ilmu Pendidikan, 2(1) (2020) 55-61. DOI: $10.31004 /$ edukatif.v2i1.89.

[3] K. Goldschmidt, The COVID-19 Pandemic: Technology use to Support the Wellbeing of Children, Journal of pediatric nursing, 53 (2020) 88. DOI: 10.1016/j.pedn.2020.04.013.

[4] R. Goudzward, Mike; Finkelstein, Adam; Petersen, LearningOS: The Now Generation Digital Learning Environment, $2017 . \quad$ URL: https://er.educause.edu/articles/2017/8/learningosthe-now-generation-digital-learning-environment

[5] Andrian, Perspektif Guru Sebagai Agen Pembaharu (Agent Of Change) Dalam Meningkatkan Kualitas Pendidikan Kewarganegaraan, Comput. Ind. Eng, 2(1) (2018) 6.

[6] R. Lestiyanawati, The Strategies and Problems Faced by Indonesian Teachers in Conducting elearning during COVID-19 Outbreak, Culture, Literature, Linguistics, and English Teaching, 2(1) (2020) 71-82. DOI: 10.32699/cllient.v2i1.1271.

[7] C. Coman, L. G. Țîru, L. Meseșan-Schmitz, C. Stanciu, M. C. Bularca, Online teaching and learning in higher education during the coronavirus pandemic: Students' perspective, 
Sustainability, 12(24) (2020) 10367, DOI: $10.3390 /$ su122410367.

[8] W. Bao, COVID - 19 and online teaching in higher education: A case study of Peking University Human Behavior and Emerging Technologies, 2(2) (2020) 113-115. DOI: 10.1002/hbe2.191.

[9] G. Basilaia, D. Kvavadze, Transition to Online Education in Schools during a SARS-CoV-2 Coronavirus (COVID-19) Pandemic in Georgia, Pedagogical Research, 5(4) 2020, DOI: $10.29333 / \mathrm{pr} / 7937$.

[10] A. Abidah, H. N. Hidaayatullaah, R.M. Simamora, D. Fehabutar, L. Mutakinati, "The Impact of Covid19 to Indonesian Education and Its Relation to the Philosophy of 'Merdeka Belajar, Studies in Philosophy of Science and Education, 1(1) (2020) 38-49. DOI: 10.46627/sipose.v1i1.9.

[11] J.W. Kusuma, H. Hamidah, Perbandingan Hasil Belajar Matematika Dengan Penggunaan Platform Whatsapp Group Dan Webinar Zoom Dalam Pembelajaran Jarak Jauh Pada Masa Pandemik Covid 19, Jurnal Ilmiah Pendidikan Matematika, 5(1) (2020). DOI: 10.26877/jipmat.v5i1.5942.

[12] S.G. Salvo, K. Shelton, B. Welch, African american males learning online: Promoting academic achievement in higher education, Online Learning, 23(1) (2019) 22-36. DOI: 10.24059/olj.v23i1.1390.

[13] K.L. Peel, Everyday classroom teaching practices for self-regulated learning, Issues in Educational Research, 30(1) (2020) 260-282.

[14] V.A. Pokrovskaya, E.M. Lychkovskaya, L.E. Molodtsova, Foreign language e-learning course as an element of city infrastructure for cognitive enhancement for the third age people. Switzerland: AG: Springer, Cham, 2020.

[15] N. Morze, I. Vorotnykova, R. Makhachashvili, Elearning Specialists Training for IT Infrastructure of an Educational Institution Management, International Journal of Research in E-learning, 3(1) (2017) 11-26.

[16] S. Suciati, Interaksi Kesiapan Belajar Dan Kepuasan Terhadap Layanan Pada Pembelajaran Online Program Pascasarjana, Cakrawala Pendidikan, 38(1) (2017) 70-80. DOI: 10.21831/cp.v36i1.12733.

[17] B. Maunah, Dampak Regulasi Di Bidang Tik Terhadap Perubahan Perilaku Sosial Siswa Di Sekolah, Jurnal Cakrawala Pendidikan, 15(2) (2016) 176-186. DOI: 10.21831/cp.v15i2.8953.
[18] A. Obiakor, T. Adeniran, Covid-19 Impending Situation Threatens to Deepen Nigeria's Education Crisis, Central Study Economic, Africa, 2020.

[19] L. D. Herliandry, N. Nurhasanah, M. E. Suban, H. Kuswanto, Pembelajaran Pada Masa Pandemi Covid-19, Jurnal Teknologi Pendidikan, 22(1) (2020) 65-70. DOI: 10.21009/jtp.v22i1.15286.

[20] A. Garad, A. M. Al-Ansi, I. N. Qamari, The role of e-learning infrastructure and cognitive competence in distance learning effectiveness during the covid19 pandemic,"Cakrawala Pendidikan, 40(1) (2021) 81-91. DOI: 10.21831/cp.v40i1.33474. 